NBER WORKING PAPER SERIES

\author{
INTEREST ALLOCATION \\ RULES, FINANCING PATTERNS, \\ AND THE OPERATIONS OF \\ U.S. MULTINATIONALS
}

Kenneth A. Froot

James R. Hines, Jr.

Working Paper No. 4924

\author{
NATIONAL BUREAU OF ECONOMIC RESEARCH \\ 1050 Massachusetts Avenue \\ Cambridge, MA 02138 \\ November 1994
}

We are grateful to Paul O'Connell for outstanding research assistance, and to Julie Collins for helptul comments on an earlier draft. Generous research support was provided by the NBER, the Division of Research at Harvard Business School, and the National Science Foundation (Grant No. SES-9209373). This paper is part of NBER's research programs in International Trade and Investment, Intemational Finance and Macroeconomics, and Public Economics. Any opinions expressed are those of the authors and not those of the National Bureau of Economic Research.

(C) 1994 by Kenneth A. Froot and James R. Hines, Jr. All rights reserved. Short sections of text, not to exceed two paragraphs, may be quoted without explicit permission provided that full credit, including $(\odot$ notice, is given to the source. 


\title{
INTEREST ALLOCATION \\ RULES, FINANCING PATTERNS, AND THE OPERATIONS OF \\ U.S. MULTINATIONALS
}

\begin{abstract}
This paper examines the impact of the 1986 change in U.S. interest allocation rules on the investment and financing decisions of American multinationals. The 1986 change reduced the tax deductibility of the interest expenses of firms with excess foreign tax credits. The resulting increase in the cost of debt gives firms incentives to substitute away from using debt finance. Furthermore, to the extent that perfect financing substitutes are not available. the overall cost of capital rises as well. The empirical tests indicate that the loss of tax deductibility of parent-company interest expenses appears to reduce significantly borrowing and investing by firms with excess foreign tax credits. The same firms tend to undertake new lease commitments, which may reflect the use of leases as alternatives to capital ownership. In addition, firms affected by the tax change tend to scale back the scope of their foreign and total operations. These results are consistent with the hypothesis that firms substitute away from debt when debt becomes more expensive, and also with the hypothesis that the loss of interest tax shields increases a firm's cost of capital.
\end{abstract}

Kenneth A. Froot Morgan 391

Harvard Business School

Harvard University

Boston, MA 02163

and NBER
James R. Hines, Jr. John F. Kennedy School of Government Harvard University 79 John F. Kennedy Street Cambridge, MA 02138 and NBER 


\section{Introduction}

International business operations pose special tax problems for multinational firms as well as the governments that tax them. Multinational firms often centralize certain activities that generate returns in more than one country. For example, firms may borrow money in one country in order to deploy the funds elsewhere. Firms are entitled to claim tax deductions for interest costs, but countries in which they borrow may not permit all of the associated interest expenses to be deducted against local income for tax purposes. The method used to calculate allowable interest tax deductions can, in turn, affect finasicing choices and operating decisions.

American tax law permits only incomplete deductibility of the interest expenses of multinational firms. U.S. law specifies rules that determine the extent to which interest costs incured by multinational firms in the United States can be deducted for tax purposes against U.S. income. These rules are often changed, the last major change occuring in 1986.

This paper examines the impact on firm behavior of the change in the U.S. interest allocation rules introduced by the Tax Reform Act of 1986 . The 1986 Act significantly reduced the tax deductibility of the U.S. interest expenses of certain American multinational corporations.

Congress changed the law in 1986 because it was concerned that some U.S.-based firms received tax deductions fur interest expenses in the United States that enhanced their profits overseas. The 1986 Act introduced a new formula for multinational firms to use in calculating the fraction of their interest expenses that can be deducted against taxable income in the United States.

This tax change increased the tax liabilities of certain American multinationals, and made additional borrowing more expensive for these firms. One of the concerns raised during the deliberations over the 1986 Act was that this additional cost of borrowing might discourage some tirms from investing in new plant and equipment, since a sizable fraction of new investment is financed by borrowing. The object of this paper is to examine the impact of the tax change on the operations of those multinational firms that were affected by the change in interest allocation rules. 
To do so, it is necessary to compare the behavior of the affected firms to the behavior of those firms that were unaffected by the interest allocation provisions of the 1986 Act.

The resuits indicate that the change in interest allocation rules significantly influenced the operations of American multinational firms. Firms that were unable to deduct all of their interest expenses against their U.S. tax liabilities issued 4.2 percent less debt between 1986-1991 (measured as a fraction of total firm assets), and invested 3.5 percent less in property, plant, and equipment, than did other firms. In addition, the affected firms showed a greater proclivity to lease rather than own capital assets, and to reduce the scope of their foreign operations. All of these behavioral responses are consistent with the incentives created by the interest allocation provisions of the Tax Reform Act of 1986.

Section II describes the U.S. tax treatment of the interest expenses of multinational corporations, and analyzes the incentives created by the Tax Reform Act of 1986. Section III describes the data used to analyze the impact of the 1986 tax change. Section IV presents the results of regressions that estimate the impact of the 1986 tax change on various aspects of the operations of American multinational firms. Section $\mathrm{V}$ is the conclusion.

\section{The Tax Treatment of Interest Expense}

This section describes the tax treatment of interest expenses of U.S. corporations, paying special attention to the treatment of multinational corporations. The object of this section is to identify the incentives created by the Tax Reform Act of 1986, as a prelude to analyzing the impact of the Act on the behavior of U.S. firms.

Interest expenses are generally deductible against the taxable income of U.S.

corporations. There are, however, two important circumstances in which the deductibility of interest is of limited value to an interest-paying corporation. The first arises when a corporation has negative 
profits before interest deductions. Since a firm with losses pays no taxes, interest deductions do not reduce its tax liability. Corporations are, however, permitted to carry net operating losses backward up to three years or forward up to fifteen years. The second circumstance is one in which a firm is subject to the corporate Alternative Minimum Tax (AMT); firms paying the AMT face idiosyncratic tax incentives. ${ }^{2}$

\section{A. Furtign and Domestic Allocation of Interest Deductions}

Special problems arise in allocating the interest deductions of multinational firms. The idea that underlies U.S. law is that, when a multinational firm incurs interest expense in the Unitad States, a certain fraction of the expense should be allocated as a deduction against taxable domestic income, and the remainder allocated against the firm's foreign income. The respective fructions are deternined on the basis of the income-generating capacity created by the loans on which interest is paid. The extreme difficulty that this concept encounters is that it is not always clear to what extent a particular loan generales domestic-source and foreign-source income.

In order (1) understand the significance of the sourcing of interest deductions, it is necessary to review the treatment of foreign-source income. Due to some peculiarities of the changes in U.S. tax liaw after 1986 , certain firms found that the cost of debt changed significantly between 1986 and 1987. The gual of the empirical work described in section 3 is to follow and compare the behavior of those firms facing higher costs of debt to those firms facing unchanged cost of debt.

'Tax loss carryforwards do not accrue interest, a feature that limits their value even to firms that expect to have taxable protits in the future. Scholes and Wolfson (1992) analyze the value of tax loss carryforwards in uncertain environments.

F For the remainder of the paper, we analyze taxpaying firms that are not subject to the AMT. Lyon and Silverstein (1993) report that $30.7 \%$ of firms with assets over $\$ 500$ million paid the AMT in 1990. 


\section{B. US Taxation of Foreign Income}

The United States taxes income on a "residence" basis, meaning that American corporations and individuals owe taxes to the U.S. government on all of their worldwide income, whether earned in the United States or not. The top U.S. corporate tax rate is now 35 percent. Since foreign profits are usually taxed in host countries, U.S. law provides a foreign tax credit for income taxes (and related taxes) paid to foreign governments in order not to subject American multinationals to double taxation. With the foreign tax credit, a U.S. corporation that earns $\$ 100$ in a foreign country with a 12 percent tax rate (and a foreign tax obligation of $\$ 12$ ) pays only $\$ 23$ to the U.S. government, since its U.S. corporate tax liability of $\$ 35$ (35 percent of $\$ 100$ ) is reduced to $\$ 23$ by the foreign tax credit of $\$ 12$. The foreign tax credit is, however, limited to U.S. tax liability on foreign income; if, in the example, the foreign tax rate were $\mathbf{5 0}$ percent, then the firm pays $\$ 50$ to the foreign government but its U.S. foreign tax credit is limited to $\$ 35$. Hence, a U.S. firm receives full tax credits for its foreign taxes paid only when it is in a "deficit credit" position, i.e., when its average foreign tax rate is lower than its tax rate on domestic operations. A firm has "excess credits" if its available foreign tax credits exceed U.S. tax liability on its foreign income." Firms average together their taxable incomes and taxes paid in all of their foreign operations in calculating foreign tax credits and the foreign tax credit limit.

Deferral of U.S. taxation of certain foreign earnings is another important feature of the U.S. international tax system. A U.S. parent firm is taxed on its subsidiaries' foreign income only when returned ("repatriated") to the parent corporation. This type of deferral is available only to foreign operations that are separately incorporated in foreign countries ("subsidiaries" of the

\footnotetext{
${ }^{3}$ Parts of this brief description of the tax system are excerpted from Hines (1991).
}

${ }^{4}$ Furthermore, income is broken into different functional "baskets" in the calculation of applicable credits and limits. In order to qualify for the foreign tax credit, firms must own at least $10 \%$ of a foreign affiliate, and only those taxes that qualify as income taxes are creditable. 
parent) and not to consolidated ("branch") operations. The U.S. government taxes branch profits as they are earned, just as it does profits earned within the United States.

The deferral of U.S. taxation may create incentives for firms with lightly-taxed foreign earnings to delay repatriating dividends from their foreign subsidiaries.s This incentive arises in those cases in which firms expect never to repatriate their foreign earnings, or if they anticipate that future years will be more attractive for repatriation (either because domestic tax rates will be lower, or because future sources of foreign income will generate excess foreign tax credits that can be used to uffset U.S. tax liability on the dividends). ${ }^{6}$ It appears that, in practice, U.S. multinationals choose their dividend repatriations selectively, generally paying dividends first out of more heavily taxed foreign earnings.' Consequently, the average tax rate that firms face on foreign income need not exactly equal the average foreign tax rate faced by their branches and subsidiaries abroad.

Branch earnings and dividends from subsidiaries represent only two forms of foreign income for U.S. income tax purposes. Interest received from foreign sources also represents foreign income, though fureign interest receipts from high-tax countries are assigned their own "basket" and therefure are nut averaged with uther incone in calculating the foreign tax credit. Royalty incume received from foreigners, including foreign affiliates of U.S. firms, is also foreign source incume.

'The incentive to defer repatriation of lightly taxed subsidiary earnings is attenuated by the Subpart F provisions, introduced in U.S. law in 1962, that treat a subsidiary's passive income, and income invested in U.S. property, as if it were distributed to its American owners, thereby subjecting it to immediate U.S. taxation. The Subpart F rules apply to controlled foreign corporations, which are foreign corporations owned at least $50 \%$ by U.S. persons holding stakes of at least $10 \%$ each. Controlled foreign corporations that reinvest their foreign earnings in active businesses can continue to defer any U.S. $\operatorname{tax}$ liability on those earnings. See Hines and Rice (1994) and Scholes and Wolfson (1992) for the behaviural implications of these rules.

'It is interesting to note that the size of the tax obligation triggered by repatriation does not itself create an incentive to delay paying dividends from foreign subsidiaries, since the U.S. tax must be paid eventually. See Hartman (1985).

${ }^{7}$ See the evidence presented in Hines and Hubbard (1990). 
Foreign governments often impose moderate taxes on dividend, interest, and royalty payments from foreign affiliates to their American parent companies; these withholding taxes are fully creditable against an American taxpayer's U.S. tax liability on foreign income.

\section{Interaction of Interest Expense and Foreign Income Rules}

American firms with foreign income are generally not permitted to deduct all of their interest costs in the United States against their domestic taxable incomes. Instead, the law provides for various methods of allocating interest expenses between domestic and foreign income. The intention of the law is to retain the full deductibility of interest expense against taxable U.S. income, but only for that part of interest expense generating income that is subject to U.S. taxation.

From the standpoint of taxpaying firms, the U.S. tax law's distinction between domestic and foreign interest deductions is potentially quite important. If interest expense is deemed to be domestic, then it is deductible against the taxpayer's U.S. taxable income. Alternatively, if it is deemed to be foreign, then the interest expense reduces foreign taxable income for the purposes of U.S. income faxation only. Foreign governments do not use U.S. methods of calculating interest deductions, and generally do not permit U.S. firms to reduce their taxable incomes in foreign countries on the basis of interest expenses incurred in the United States. Consequently, interest expenses allocated against foreign income are valuable to a U.S. firm only if it has deficit foreign tax credits. If it does have deficit credits, then some of the firm's foreign income is subject to U.S. tax, and any additional dollar of interest expense allocated against foreign income reduces the firm's U.S. taxable income by a dollar. With deficit foreign tax credits, firms are indifferent between allocating

"Curiously, the law is written so that the additional dollar of interest expense reduces taxable income without reducing the foreign tax credits available for foreign income taxes paid. 
interest expenses against foreign income and allocating them against domestic income.? If, on the other hand, firms have excess foreign tax credits, then any interest expenses allocated against foreign income are useless from the standpoint of reducing tax liabilities, since foreign income generates no U.S. tax liability anyway.

The Tax Reform Act of 1986 significantly changed U.S. tax law governing the allocation of interest expenses. Prior to 1986, the interest expenses of U.S. taxpayers were determined separately for each company within a controlled group. ${ }^{10}$ In principle, each company was required to al locate interest deductions between domestic and foreign source in proportion to domestic and foreign assets." In practice, however, this rule permitted taxpayers to structure their finances in order to obtain a full tax deduction in the United States for interest expenses associated with burrowing done in the United States.

Consider, for example, the situation of an American corporation that borrows $\$ 100$ in

'This statement, along with much of the analysis described in the paper, abstracts from the ability of firms to carry excess foreign tax credits backward two years and forward five years. Firms that carry excess credits forward or back may (depending on specific circumstances) face incentives that are intermediate between those of deficit credit and excess credit firms.

"Separate allocation of interest deductions for each company within a controlled group was firmly established by Treasury Regulation $\$ 1.861-8$, issued in 1977. Prior to 1977, US law was somewhat vague about whether all of the companies within a controlled group should be consolidated for purposes of interest allocation, though in an important case based on pre-1977 US law, (ITT v. Unised States) the courts held that interest should be allocated on a consolidated basis.

"Taxpayers were given the alternative of allocating interest deductions on the basis of gross domestic income and gross foreign income, though it is hard to understand why a tax-minimizing corporation would do so, since tax-planning opportunities are so attractive using the asset method on a single-company basis. The regulation provides that, if the income method is chosen, interest deductions allocated against foreign-source income cannot be less than $50 \%$ of the amount that would have been allocited against foreign-source income by the asset method. Taxpayers allocating their interest deductions on the basis of domestic and foreign assets were required to do so based on the hook values of those assets, unless the taxpayer elected to allocate on the basis of fair market values, and could demonstrate fair market values to the satisfaction of the IRS. Once chosen, taxpayers were required to continue to use the fair market value method until granted permission by the IRS to discontinue its use. Book values of stuck (such as a parent corporation's stock in its foreign subsidiaries) were not adjusted to include undistributed earnings and profits reinvested by the subsidiary corporations. 
the United States, paying interest of $\$ 10$ annually. The corporation has $\$ 150$ of U.S. assets and $\$ 50$ of foreign assets, and earns profits of $\$ 15$, gross of interest costs, in the United States, and profits of $\$ 5$ abroad. The corporation does no foreign borrowing. Under pre-1986 law, this corporation would be entitled to deduct only $\$ 7.50(75 \%$ of $\$ 10)$ of its interest charges against U.S. income, since only $75 \%$ of its assets produce U.S.-source income; the remaining $\$ 2.50$ of interest deductions would be allocated against foreign-source income. The same firm, with the same real business activities, could, however, reorganize its affairs in a manner that would permit all of the $\$ 10$ interest cost to be deductible against U.S. income. To do so, the parent firm need only borrow the $\$ 100$ in the U.S. market and then contribute the money as paid-in capital to a wholly-owned domestic subsidiary that owns the firm's domestic and foreign operations. The domestic subsidiary pays all of its profits to its parent as dividends. The parent firm and the domestic subsidiary file a consolidated tax return and annual report. The domestic subsidiary has $\$ 15$ of U.S.-source income and $\$ 5$ of foreign-source income; it has no interest expenses. The parent firm has $\$ 20$ of income on the basis of dividends received from its subsidiary, and $\$ 10$ of interest deductions. The parent firm is entidled to deduct all of its interest expense against U.S. income, since the firm's assets (its wholly-owned subsidiary) are all in the United States. ${ }^{12}$

The Tax Reform Act of 1986 significantly changed the method by which interest deductions are allocated, specifically by introducing a "one-taxpayer rule" in which the attributes of all members of a controlled group - whether owned directly by a parent firm or owned by the parent through one or more subsidiaries - determine the allocation of interest deductions between domestic

"Prior to 1986, U.S. law did not use sophisticated "look-through" rules to determine the extent to which a U.S. corporation represents a U.S. asset. Instead, a U.S.-located subsidiary was considered to be a U.S. asset as long as $20 \%$ or more of its gross income for the prior three years had U.S. source. In the example, $75 \%$ of the domestic subsidiary's gross income has U.S. source. 
and foreign income. ${ }^{13}$ The motivation for the tax change was the insight that financial fungibility implies that borrowing by one part of a controlled group directly or indirectly influences the economic activities of all of the group. The 1986 Act provides that the interest expenses of a U.S. taxpayer should be allocated between domestic-source and foreign-source income based on the relative assets of the domestic and foreign operations of the controlled group. Of course, several complications attend the implementation of such a rule.

Controlled groups represent chains of $80 \%$ or greater ownership. Consequently, an American parent corporation that owns $75 \%$ of the voting stock of a domestic subsidiary, the other $25 \%$ of which is owned by unrelated parties, separately allocates the interest deductions of the parent corporation and the domestic subsidiary. The $80 \%$ rule corresponds to the requirements for filing consolidated tax returns and annual reports. The interest expenses of foreign corporations are never included within the controlled group for purposes of interest expense allocation. ${ }^{14}$

Taxpayers are required to allocate interest deductions between domestic and foreign source on the basis of the book values of assets held domestically and abroad. ${ }^{\text {is }}$ In the cases of subsidiaries that are 10\% or more owned by members of the affiliated group, the book values of stock held in the subsidiaries are adjusted to reflect accumulated earnings and profits of the subsidiaries.

\footnotetext{
12The changes in the interest allocation rules introduced by the Tax Reform Act of 1986 were phased in over three years. Various phase-in rules apply to the interest on debt issued between 1983 and 1985.

"There is an exception for financial institutions whose business is primarily with unrelated parties and that are required by law to be operated separately from nonfinancial institutions. Such financial institutions are not included with the rest of an affiliated group for purposes of interest allocation; instead, the financial institutions are treated as a separate entity for purposes of interest allocation. Special rules also apply to corporations claiming the U.S. possessions tax credit (available under 8936): these corporations are included in the consolidated group for purposes of interest expense allocation if they otherwise meet all of the requirements for inclusion.
}

19Taxpayers have the alternative of using the fair market values of assets held domestically and abroad, but if taxpayers do so, they are not again able to use book values without permission of the IRS. 
Hence, in the case of an American firm that initially finances its wholly-owned French subsidiary with $\$ 100$ of equity, and in which the subsidiary subsequently earns and reinvests an additional $\$ 400$, the parent's book value of the subsidiary is adjusted to $\$ 500$ for purposes of interest expense allocation.

The 1986 Act provides for a curious treatment of foreign assets and foreign interest deductions by members of a controlled group. For this purpose, the gross value of U.S. assets and the net value of foreign assets are used. This leads to something of an asymmetric treatment of foreign and domestic borrowing for purposes of interest expense allocation. Consider, for example, the case of a U.S. firm that has $\$ 200$ of U.S. assets, of which $\$ 150$ is equity and $\$ 50$ is debt borrowed from an unrelated party; the firm also has $\$ 200$ of foreign assets, of which $\$ 150$ is parent equity and $\$ 50$ is debt borrowed by the subsidiary from an unrelated foreign party. The firm has U.S.-source gross income of $\$ 40$, U.S. interest cost of $\$ 5$, foreign-source gross income of $\$ 40$, and foreign-source interest expense of $\$ 5$. This firm is required to allocate almost half of its $\$ 5$ domestic interest deduction against foreign-source income, ${ }^{16}$ and the firm is not permitted to allocate any of its foreign interest expense against domestic-source income, even though the leverage situation of the foreign subsidiary is the same as the leverage situation of its American parent.

One of the consequences of the asymmetric treatment of U.S. parent firms and their foreign subsidiaries is that the tax law can encourage firms to finance their subsidiaries with debt from the American parent instead of parent equity or unrelated-party debt. Parent equity in foreign subsidiaries reduces the amount of domestic interest payments allocated against U.S.-source income. If, in the previous example, the subsidiary borrowed $\$ 50$ from its parent company instead of from an unrelated party, and the parent financed the loan to its subsidiary by borrowing an additional $\$ 50$

1"The firm has domestic assets of $\$ 200$ and foreign book assets of $\$ 150$, so it allocates foursevenths ( $\$ 200 / \$ 350)$ of its domestic interest expense against domestic-source income, and the remaining three-sevenths against foreign-source income. 
from unrelated U.S. parties, then the subsidiary's tax position would not change (it still gets a $\$ 5$ deduction against taxable tncome in the foreign country for interest paid to its U.S. parent), ${ }^{17}$ but the parent firm receives a larger interest deduction against U.S.-source income.

The U.S. Treasury issued regulations designed to prevent U.S. firms from reacting to the passage of the 1986 Act by financing their foreign subsidiaries with loans from U.S. parents financed by U.S. borrowing. The first set of regulations was proposed in 1987 but never took effect." A second set of regulations was proposed in 1988, and was temporarily in effect from that time until 1991. Under the 1988 regulations, related-party debt influences interest allocation only if the U.S. parent company's ratio of third-party borrowing to total assets differs significantly from its foreign subsidiaries' (aggregate) ratio of third-party borrowing to total assets. The idea is to flag situations in which foreign subsidiaries route their third-party borrowing through their American parent companies. The 1988 regulation requires donestic interest expense to be allocated to foreign source if foreign subsidiaries' aggregate ratio of third-party indebtedness to total assets is less than $80 \%$ of the third-party indebtedness of the U.S. parent company. ${ }^{10}$ If such cases, domestic interest

${ }^{17}$ Subject to two qualifications. Certain countries (including the United States) impose "thincapitalization" laws that limit the amount of related-party interest foreign firms can deduct from local taxable income. In addition, countries often impose withbolding taxes on cross-border interest payments; U.S. firms with deficit foreign tax credits receive foreign tax credits for paying these taxes. Withholding taxes on interest are usually reduced, often to zero, by bilateral tax treaties.

10The 1987 proposal was ultinately dropped due to its draconian impact on certain taxpayers with extensive fureign operations. The 1987 proposal would have first allocated domestic interest expense against foreign income to the extent of any related-party interest receipts from controlled foreign corporations of the American parent company. Remaining dogiestic interest expense would then be allocated between U.S. and foreign source on the basis of assets. Hence, a firm with $\$ 100$ of interest expense from borrowing by the U.S. parent in the United States, and $\mathbf{\$ 2 0}$ of interest receipts from its foreign subsidiary, would first allocate $\$ 20$ of its U.S. interest expense against foreign income, and allocate the remaining $\$ 80$ of interest expense between foreign and domestic sources based on relative assets.

The temporary regulation phased in the $80 \%$ requirement: the criterton was $50 \%$ for $1988,65 \%$ for 1989 , and $80 \%$ for 1990 and subsequent years. 
expenses are allocated against foreign-source income until the third-party indebtedness of foreign subsidiaries plus domestic interest expenses, allocated in this way, equal remaining domestic-source third-party interest expenses. Remaining domestic interest expenses are then allocated between U.S. and foreign source according to the $\$ 861-8$ statute.

The interest allocation rule just described is likely to have some curious effects on the actions of those firms that are bound by the $80 \%$ requirement. The 1988 regulations were, however, supplanted by new regulations in 1991, and taxpayers have the option of recalculating their prior tax liabilities using the new regulations in place of the 1988 regulations for every year that the 1988 regulations apply. At the time that the 1987 and 1988 regulations were proposed, many observers anticipated that they would be replaced by somewhat more flexible rules that would be made retroactively applicable. Consequently, it is unlikely that the 1988 regulations had an important effect on firm behavior.

The 1991 regulations compare current-year behavior of U.S. parent companies to their behavior over 5-year "base periods." Specifically, the regulations provide that domestic interest expense deductions are allocated against foreign source income if both (i) third-party indebtedness of the U.S. parent and (ii) lending by the U.S. parent to its foreign subsidiaries exceed base levels (adjusted for acquisitions, dispositions, and changes in amounts of assets). Various exceptions apply to firms for whom the adjustment would be a small matter, and firms that experience large year-toyear changes in their borrowing behavior. Once this intrafirm interest expense allocation is complete, remaining domestic interest expenses are allocated to foreign source based on the $\$ 861-8$ statute.

Given the complexity of the 1991 regulation, and the important role it gives to a firm's past behavior, it appears that the incentives it creates can be very firm-specific. In what follows, firms are assumed not to be bound by the base-period ratio tests.

There are exceptions to the allocation rules introduced in the 1986 Act. One 
exception concerns interest on certain non-recourse debt. Taxpayers are permitted to allocate all of their interest expenses against income derived from property acquired using non-recourse debt, subject to various restrictions. Consequently, an American multinational that finances a $\$ 100$ dumestic investment with $\$ 60$ of equity and $\$ 40$ of non-recourse debt is entitled to deduct the interest expenses generated by the $\$ 40$ debt from the income flow of the $\$ 100$ investment in calculating its taxable income. ${ }^{30}$ There is a second exception in which nonfinancial furms are permitted to deduct interest expenses on debt used to purchase interest-bearing securities against the interest income from those securities, again subject to certain restrictions.

\section{Incentives Created By The Tax Rules}

The upshot of the rules just described is that firms with excess foreign tax credits and substintial foreign assets (as a fraction of total assets) could no longer enjoy the benefits of full deductibility of interest expenses incurred in the United States after 1986. Firms with deficit foreign tax credits, or those with no foreign assets, retain full benefits of interest expense deductibility. As a consequence, firms in the first category can be expected to reduce their borrowing relative to firms in the second, and can also be expected to reduce the volume of their debt-financed investment activity. ${ }^{21}$

${ }^{20}$ The use of non-recourse debt in a situation like this one offers a tax advantage, but is costly in that lenders typically require higher interest rates to compensate for the additional risks they bear due to the non-recourse nature of the debt.

${ }^{21}$ Three other studies examine the impact of interest al location rules on the bebavior of impacted firms. Collins and Shackel ford (1992) find that firms with large ratios of foreign to domestic assets are more likely than other firms to issue preferred stock (as a substitute for debt) in the period after 1986. Collins and Shackelford do not, however, distinguish excess foreign tax credit firms from deficit foreign tax credit firms. Altshuler and Mintz (1994) analyze the borrowing patterns of a sample of eight multinational firms, finding that firms that are unable to claim full tax deductions for interest payments in the United States are more likely to borrow abroad than to borrow in the United States. Froot and Hines (1994) examine the effect of interest allocation rules on the financing patterns of firms as they grow, finding that the tax change discouraged some firms from adding new assets to their balance sheets. 
In order to analyze more carefully the incentives created by changes in the U.S. tax treatment of interest deductions, it is helpful to examine firm behavior within a very stylized model. We assume that an American firm's domestic profits after depreciation and other expenses (but before interest charges) is $\mathrm{Q}(\mathrm{A})$, in which A represents domestic assets. Foreign profits after depreciation and other expenses including interest charges on foreign borrowing is $Q^{*}\left(A^{*}\right)$, in which $A^{*}$ represents foreign assets net of foreign borrowing. Domestic assets have two components: equity (E) and debt (D), so $A=E+D$. The interest rate on domestic borrowing is $r$, the domestic corporate tax rate is $\tau$, and the foreign tax rate is $\tau^{*}$. Firms are assumed to repatriate their foreign after-tax profits as earned, and the foreign withholding tax rate on dividend repatriations is assumed to be zero.

We use $\alpha$ as an indicator variable that takes the value $l$ if the firm has excess foreign tax credits (in this model, $\alpha=1$ if $\tau^{*}>\tau$ ), and 0 if the firm has deficit foreign tax credits. A firm is required to allocate domestic interest deductions of $r D\left[A^{*} /\left(A+A^{*}\right)\right]$ against foreign-source income. Firms with deficit foreign tax credits are unaffected by this requirement, while the after-tax profits of firms with excess foreign tax credits are reduced by the product of this amount and the statutory U.S. tax rate. The foreign operations of firms with deficit foreign tax credits are effectively taxed at the U.S. tax rate, while the foreign operations of firms with excess foreign tax credits are effectively taxed at foreign tax rates.

Firms are assumed to maximize total after-tax profits, which equal:

Profits $=[Q(E+D)-r D](1-\tau)-\alpha \pi D\left[A^{*} /\left(E+D+A^{*}\right)\right]+Q^{*}\left(A^{*}\right)\left[1-\alpha \tau^{*}-(1-\alpha) \tau\right]-\lambda A^{*}$

in which $\lambda$ is the shidow cost of resources devoted to foreign operations. Consider first the behavior of firms with excess foreign tax credits. Setting $\alpha=1$, and solving for an interior maximum of (1) over the choice of $D$, yields: 


$$
Q^{\prime}(A)=r+r \tau A^{*}\left(E+A^{*}\right) /\left[(1-\tau)\left(E+D+A^{*}\right)^{2}\right]
$$

Solving for an interior maximum of (1) over the choice of $A^{*}$ yields:

$$
\mathrm{Q}^{* \prime}\left(\mathrm{A}^{*}\right)=\lambda+r \tau \mathrm{D}(\mathrm{E}+\mathrm{D}) /\left[(1-\tau)\left(\mathrm{E}+\mathrm{D}+\mathrm{A}^{*}\right)^{2}\right]
$$

By contrast, the first-order conditions that characterize the behavior of firms with deficit foreign tax credits $(\alpha=0)$ are:

$$
\begin{aligned}
& Q^{\prime}(A)=r \\
& Q^{* \prime}\left(A^{*}\right)=\lambda
\end{aligned}
$$

Examination of equations (2) - (5) indicates that the interest allocation rules raise the required marginal product of debt-financed domestic and foreign capital for firms with excess foreign tax credits. The degree to which required marginal products are raised depends, in part, on terms that include ratios of domestic indebtedness and domestic assets to the square of total assets. The squared terms appear due to the conflicting effects of interest allocation on the demand for domestic and foreign assets. Interest allocation raises the after-tax cost of marginal debt used to finance the domestic operations of firms with excess foreign tax credits. At the same time, interest allocation encourages firms with excess foreign tax credits to expand their domestic operations in order to allocate as much as possible of their inframarginal domestic interest expense against U.S.-source income. The combination of these two effects attenuates, but does not eliminate, the direct effect of interest allocation on the demand for domestic assets. Interest allocation raises the required marginal 
product of foreign capital through its effect on the allocation of inframarginal interest expenses for firms with excess foreign tax credits.

One complication that arises in using (2)-(5) to estimate the effect of interest allocation rules on firm behavior after 1986 is that foreign and domestic asset levels are themselves endogenous to the tax changes under consideration. We treat this problern by using 1986 levels of $\left[A^{*} /\left(A+A^{*}\right)\right]$ in the regressions as proxies for contemporaneous foreign asset fractions. Since foreign asset fractions did not influence the allocation of interest deductions in 1986, the 1986 level of this variable is arguably exogenous to the change in behavior induced by the tax change. Of course, more sophisticatad treatments are possible, such as instrumenting for contemporaneous foreign asset fractions with the 1986 fraction, or parameterizing the model to include endogenously the tax-induced changes in the fraction of foreign and domestic assets. One of the difficulties that such investigations encounter is that available data are sketchy, and in particular, that asset and foreign tax credit information does not correspond exactly to definitions that apply for tax purposes. In addition, richer models that incorporate possible substitutability or complementarity of domestic and foreign assets are likely to suggest subtle variants of the procedure described above. Given the limitations inherent in using publicly-available data, we proceed to analyze simple specifications of the relationships implied by (2)-(5).

\section{Data and Preliminary Results}

We use information reported by Compustat on the balance-sheet items of large publicly-traded corporations. Compustat currently provides information on somewhat more than 7,500 companies. We select only multinational firms incorporated in the United States: firms are included if their reported foreign assets equal $1 \%$ or more of reported watal assets for each year 19861990. 422 firms satisfy this criterion. 
Foreign tax rate information is central to our analysis, since the hypothesis that firms maximize after-tax profits implies that deficit foreign tax credit firms will react quite differently to the Tax Reform Act of 1986 than will excess foreign tax credit firms. We construct foreign tax rates as the ratio of foreign income taxes paid to foreign pre-tax income as reported by Compustat. This variable is somewhat noisy, but is likely to capture the major differences between the foreign tax rates facing different firms. ${ }^{2}$ In order to attenuate some of the difficulties that accompany annual measurements of the foreign tax rate variable, firms were classified into excess foreign tax credit status based on five years of data, 1986-1990. Firms for which the average foreign tax rate over that period exceeds the contemporaneous average U.S. statutory corporate tax rate are classified as excess foreign tax credit firms; all other firms are classified as deficit foreign tax credit firms. ${ }^{20}$ From our initial sample of $\mathbf{4 2 2}$ firms, six additional firms were excluded, five due to insufficient tax rate information, and one to major ownership changes over the 1986-1991 time period. ${ }^{24}$ Thus the total sample is $\mathbf{4 1 6}$ firms. Hand checking of the Compustat data led to the correction of two errors. ${ }^{2}$ Mergers and other dramatic business events can complicate the interpretation of

The introduction of the new interest allocation rules in 1986, along with other tax changes, gave some firms incentives to adjust the location and tax-avoiding behavior of their foreign affiliates. In the analysis that follows we take foreign tax rates to be exogenous to US tax changes. Endogenizing foreign tax rates could change the interpretation of the magnitude of the estimated coefficients.

${ }^{20}$ This classification of the foreign tax credit status of the firms in the sample is necessarily somewhat imprecise. The same firm may have excess foreign tax credits in one year and deficit foreign tax credits in another; furthermore, excess foreign tax credits may be carried forward five years or back two years. A firm's foreign tax credit status can be endogenous to discretionary decisions such as dividend repatriation choices. The regressions reported in the tables were all re-run replacing the zeroone foreign tax credit status with a continuous tax rate variable constructed as the average difference between foreign and U.S. tax rates. The results are similar to those reported in the tables.

${ }^{2 \times}$ Coltec Industries was taken private in 1988, and completed an IPO in early 1992.

sCompustat reports that Alpnet's foreign asset to total asset ratio was 1.25 in 1988, while the tirm's annual report implies that the ratio is 0.789 ; we use the latter figure. Compustat reports a jump in IBM's foreign asset to total asset ratio from 0.48 in 1990 to 0.98 in 1991. IBM's annual report indicates that the 1991 ratio was 0.469 , which is the figure we use. 
changes in the behavior of firms over the sample period. In the process of merging, firms can exhibit large changes in amounts of debt outstanding, ownership of property, plant, and equipment, and other variables that serve as indicators of reactions to changes in the interest allocation rules. One consequence is that an analyst might attribute some of these operational changes to tax incentives introduced by the $1986 \mathrm{Act}$, when, in reality, the changes are the results of merger decisions that were uninfluenced by the 1986 Act. Alternatively, the 1986 Act might be responsible for important changes in capital structure or business operations, but these changes could be swamped by the effects of mergers.

These difficulties notwithstanding, it is important to bear in mind that merging firms face the same tax incentives as do firms that do not merge. One interpretation of the potential problem introduced by mergers is that firm-specific attributes captured by the constant term used in panel estimation may not remain constant for firms that merge. At the same time, merging firms may provide the clearest indication of the behavioral responses to the tax change, since firms undergoing mergers often simuitaneously reexamine their capital structures, their needs for domestic and foreign assets, and other considerations that nonmerging firms may address only sporadically.

We address the probiem of mergers by repeating our estimation on three data sets. The first is the universe of 416 firms described above. A second data set of $\mathbf{3 8 8}$ firms excludes any firms that record a $100 \%$ or greater change in assets in one year. The idea is that firms with greater than $100 \%$ changes in assets very likely experience substantial mergers that change the character of their business decisions. The third data set, consisting of 331 firms, uses a more restrictive threshold of $50 \%$ changes of assets. Due to space limitations, we do not report below all of the results using the three data sets; instead, we report results for the largest available data set, while noting any important differences in the results that appear using the more restricted samples.

We use firm-level information available through Compustat to calculate changes over 
the 1984-1991 time period in: debt, capital in place, foreign assets, costs of goods sold, foreign sales net of intrafirm exports, taxes paid, and pretax income. Changes in debt are measured as the difference between the book values of total debt (long-term and current) in 1991 and total debt in 1986. Changes in capital are measured as the difference between net property, plant and equipment in 1991 and net property, plant, and equipment in 1986. Foreign assets are measured as total foreign assets in 1986, and the ratio of this variable to total assets in 1986 is used not only to control for firm characteristics (degree of multinationality) but as a component of the cost of debt finance after 1986. In some of the regressions, we use tax loss carry forwards (TLCF). Tax loss carryforwards are measured (for those firms reporting it) using 1986 data only. ${ }^{26}$ We use 1986 levels of TLCF due to the potential endogeneity of TLCF over the 1986-91 period (since tax losses can be generated by rapid debt accumulation). Table 1 presents means and standard deviations of variables used in the regressions.

The empirical strategy is to use the identifying assumption that foreign tax credit status influences operational changes between 1986-1991 only through its effect, via interest allocation rules, on the cost of borrowing. Of course, differences in foreign tax credit status could reflect firm heterogeneity that is (for some reason) related in a nontax manner to operational changes over 19861991. We attempt to control for firm heterogeneity in two ways. First, we use ratios of foreign assets to total assets, TLCFs, and industry dummies to allow for industry- and firm-specific effects that may be correlated with foreign tax credit status. Second, we use firm behavior over the 1984-86 period as a control for behavior from 1986-1991. If the results are driven by the 1986 tax change, foreign tax credit status should have no ability to explain changes in debt, assets, foreign operations, and other variables over the $1984-86$ period. Alternatively, if the results are driven by omitted firm-

\footnotetext{
${ }^{2}$ Information on tax loss carryforwards in 1986 is missing for 29 of the firms in the sample of 416; these firms were dropped from the sample in specifications using TLCF as an explanatory variable.
} 
specific factors that are constant over 1984-1991 and correlated with the 1986 tax variables, then results for the pre-reform (1984-86) and post-reform (1986-91) periods should look similar.

\section{Regression results}

This section describes the results of regressions that estimate the effects of the changes in interest allocation rules on firm financing and operational patterns. The null hypothesis is that the changes in interest allocation rules had no impact on firm behavior; this hypothesis implies that firms simply bear the tax cost of the 1986 Act. We contrast this null hypothesis with two alternative hypotheses: (l) that firms respond to the tax changes by using non-debt financing, and (II) that firms respond to the tax changes by reducing their foreign operations. ${ }^{27}$

We examine these alternatives by constructing independent variables that distinguish firms by thcir exposures to the tax change as of 1986. Firms with excess foreign tax credits and high ratios of foreign to domestic assets are the ones that are least able to take deductions against their U.S. tax liabilities for domestic interest payments. The foreign tax credit status dummy variable (described above) is a simple measure of firm exposure to the change in the interest allocation rules. It is possible to obtain more precision by measuring interaction effects. For example, we use the squared ratio of foreign assets to total assets, interacted with the foreign tax credit dummy variable, to

\footnotetext{
27The null and alternative hypotheses correspond to different theoretical specifications of the ease with which firms can adjust their financial and operating patterns. Stiglitz (1973) argues that the tax advantage to debt makes borrowing a firm's preferred method of financing marginal investments. If this argument is correct, and firms continue to prefer debt to other financing methods even after some of its tax advantages are lost due to the interest allocation rules, then firms will not react to the tax changes by substituting other financing methods for debt, but will react by reducing the size of foreign and total operations. Alternatively, the Miller (1977) model of financial equilibrium implies that firms impacted by the interest allocation rules will change their capital structure to pure equity finance. As long as the capitalization of the affected firms does not exceed the initial amount of equity on the market, this type of financial arbitrage implies that the interest allocation rules will not affect the capital costs, or real operations, of any firms. Gordon and Malkiel (1981) examine a model in which debt is tax-preferred but its use raises the probability that a firm will incur costs associated with bankruptcy; this model carries implications between those of the Stiglitz and Miller models.
} 
detect differences in firm behavior based on foreign tax credit status, given the ratio of assets abroad. According to the model, excess foreign tax credit firms ought to show greater behavioral responses the higher are their ratios of foreign to total assets. We also control for other firm characteristics that might be correlated with firm responses, such as growth over the sample period, industry, and presence and amount of tax loss carryforwards.

We choose dependent variables to identify changes in: (i) firm capital structure; (ii) investment spending; (iii) lease commitments; and (iv) foreign operating levels. These variables are chosen because of their relationships with the alternative hypotheses. For example, alternative hypothesis (l) implies that firms can costlessly substitute away from higher-priced debt toward other financial vehicles; this behavioral response should appear as a change in capital structure. In addition, investment spending would tend to fall and leasing to increase in excess foreign tax credit firms, as they take assets off their balance sheets through leasing. ${ }^{23}$ Finally, hypothesis (I) implies that foreign operating levels should not change in response to the 1986 Act, since managers finance costlessly around the tax change.

If alternative hypothesis (Il) is correct, substitute financial vehicles are not perfect, and consequently, the tax change raises the cost of capital in certain businesses. This increase in costs may encourage firms to cut back on their operations. We also might expect some effect on financing methods, as firms substitute away from debt and toward leasing. However, we would also expect a decline in investment and foreign operations, measured by foreign-produced foreign sales, or even by firm-wide costs of goods sold.

\footnotetext{
${ }^{24}$ Operating leases (to which we refer) are not included on the balance sheet, and the associated lease payments are fully deductible against U.S. taxable income. Capital leases on the other hand, are included on the balance sheet, and their associated lease payments are (as is true of debt) alloced for tax purposes between domestic and foreign sources by $\$ 861-8$. We use measures of investment that include changes in capital leases but not in operating leases, and it is operating leases that are preferred by firms unable to take full advantage of lease tax deductions. See, for example, Smith and Wakeman (1984) and Edwards and Mayer (1991).
} 
If the null hypothesis is correct, then firms do little to change their financing or operating patterns; instead, they simply bear the additional burden created by the tax change. If this is the case, then changes in capital structure, leasing, investment, foreign operations, and firm-wide operations need bear no relation to firms' exposures to the interest allocation provisions of the 1986 Act. However, one would expect to observe an increase in total costs (and a decline in after-tax profits) that reflects the additional tax burden.

\section{A. A Nonparametric Look at the Sample}

Table 2 describes some aspects of the behavior of the sample of firms after $1986 .{ }^{20}$ Firms are classified into two groups on the basis of fraction of foreign assets (above median and below median); within group, they are further classified by excess foreign tax credit and deficit foreign tax credit status. Roughly half of the firms in the sample (51.4\%) are classified as having excess foreign tax credits.

Firms that differ in the fraction of their assets held abroad may differ in other important observable and unobservable ways. The model presented in section 2 implies that the 1986 Act raised the cost of debt-financed investments for firms with excess foreign tax credits and significant foreign assets. The behavior described in Table 2 is consistent with the predictions of the allernative hypotheses. Firms with excess foreign tax credits exhibit slower mean growth (from 19861991) of outstanding debt relative to 1986 assets, and slower mean growth of property, plant, and equipment, than do deficit credit firms. This pattern appears for multinational firms with small fractions of foreign assets (except for a negligible difference in debt changes for excess and deficit foreign tax credit firms with small amounts of foreign assets), but is considerably more dramatic for

\footnotetext{
${ }^{20}$ Tables 2-3 describe the behavior of the sample of 388 firms that did not exhibit $100 \%$ or greater change in assets in a year. The larger sample of 416 firms has moments that are very similar to those reported in Tables 2-3.
} 
firms with high fractions of foreign assets.

Figure 1 illustrates the mean growth of debt relative to 1986 asset levels for firms in each cell reported in Table 2. The figure suggests that excess foreign tax credits affect only those firms with significant foreign assets, which is consistent with the theory sketched in section 2. Furthermore, there is a marked difference between the cumulative growth of debt in excess foreign tax credit firms and that in deficit foreign tax credit firms. A similar pattern appears in firms' accumulation of property, plant and equipment, as illustrated by Figure 2. This figure indicates that the impact of excess foreign tax credits on the accumulation of property, plant, and equipment is most dramatic for firms with significant foreign assets as a fraction of total assets.

Alternative hypothesis (I) indicates that firms react to higher after-tax costs of debt by replacing debt with alternative financing devices. Earlier work by Collins and Shackelford (1992) calls attention to the impact of changes in interest allocation rules on firms' proclivities to issue preferred stock. Only a small fraction of firms are financed with preferred stock, but they argue that the use of preferred stock expanded after 1986 due, in part, to the rising after-tax cost of debt.

Table 3 describes the responses of firms in our sample to the changing incentives to issue preferred stock after 1986. The mean behavior of firms as reported in the table is not consistent with the hypothesis that tax considerations were responsible for a significant shift of financing away from debt and into preferred stock. The absence of an important effect in the means may reflect the omission of important variables that explain preferred stock issuances, ${ }^{30}$ or may simply reflect the smallness of the fraction of the sample that ever issues preferred stock. One tidbit of evidence presented in Table 3 is consistent with the theory of tax-motivated preferred stock issuances: excess

${ }^{30}$ Collins and Shackelford (1992) include a number of additional explanatory variables in their regressions. Many of these additional variables, such as net operating loss status, are likely to influence preferred stock issuances, but most financial and operating variables are themselves endogenous to financing choices and may respond to unobservables that also influence financing decisions. 
foreign tax credit status is positively correlated with the fraction of high-foreign-asset firms that increase their outstanding preferred stock after 1986, and negatively correlated with the fraction of high-foreign-asset firms that decrease their outstanding preferred stock after 1986. The reverse pattern appears for low-foreign-asset firms. Given the very small size of the sample of firms changing their preferred stock amounts, however, these correlations are no more than suggestive.

\section{B. Capital Structure and Changes in Borrowing Patterns}

Tables 4a-b report regressions of changes in capital structure, measured as the change in debt divided by beginning-of-period assets. The sample period used in the regressions reported in Table 4a is the 1986-1991 period, whereas the sample period used in the regressions reported in Table $4 \mathrm{~b}$ is 1984-1986. All regressions are OLS.

The first specification in Table 4a regresses the change in debt from 1986 to 1991 (scialed by assets in 1986) on a constant and the foreign tax credit status dummy. The coefficient on the dummy term is negative as expected; however, it is not statistically significant. A more precise specification is that excess foreign tax credit firms should exhibit greater aversion to using debt the higher are their ratios of foreign to total assets. The second regression in Table 4a tests this specification, by including both the (squared) ratio of foreign to total assets and an interaction term between this ratio and the foreign tax credit status dummy. Here, the coefficient of -0.64 on the interaction term indicates that a firm with excess foreign tax credits and half of its assets abroad reduces its debt accumulation by $16 \%\left[-0.64(1 / 2)^{2}\right]$ of assets over 5 years, or about $3 \%$ per year.

This coefficient on the interaction term becomes larger and more significant when (as in the regressions reported in column 3) tax loss carry forwards (TLCF) are included as an explanatory variable. The introduction of industry dummy variables, intended to capture differential pressure on debt accumulation across industries, also raises the magnitude of the estimated coefficient 
that reflects the impact of interest allocation rules. In the specification reported in column 5, one that includes both TLCF and industry dummies, the estimated coefficient on the interaction term is -0.96 . This implies that the interest allocation rules encourage a firm with excess foreign tax credits and half of its assets abroad to reduce debt accumulation at an annual rate of $4.8\left[-0.96(1 / 2)^{2} / 5\right]$ percent of initial assets.

Table $4 b$ reports estimated coefficients from regressions that repeat the same 5 specifications as those reported in Table 4a, except that the dependent variable is now the change in debt prior to the tax-law change (1984-1986). If the results in Table $4 \mathrm{a}$ are driven by unobserved, time-invariant, and firm-specific factors that are correlated with included tax variables, we would expect to find the results reported in Table $4 \mathrm{~b}$ to resemble those in Table 4a. Note, however, that this is not the case: the estimated coefficients on all of the explanatory variables (except TLCF) change sign and become insignificant. Thus, Table $4 \mathrm{~b}$ offers little support for the bypothesis that firm-specific unobservables are responsible for the results reported in Table 4a." A better interpretation of the results of Tables $4 \mathrm{a}$ and $4 \mathrm{~b}$ is that excess foreign tax credit firms tend to substitute away from debt finance. As expected, this appears to be particularly true for firms with larger ratios of foreign-to-total assets.

Table 5a presents estimated coefficients from regressions that examine changes in property, plant, and equipment (PPE) from 1986 to 1991, scaled by 1986 assets. Right-hand side specifications are similar to those used in Table 4a. The first specification reported in Table 5a shows that investment rates differ by foreign tax credit status. While the coefficient on the foreign tax credit dummy variable is statistically negative, it is relatively small: excess foreign tax credit firms invest at rates that are about $1.5 \% \cdot[-0.074 / 5]$ lower per year. Note that, as before, the effect

\footnotetext{
${ }^{31}$ We ran the specifications presented in Tables $4 a-4 b$ for two smaller data samples that filter out those firms with year-on-year changes in assets of 100 and 50 precent, finding results that are similar to those above. However, in some cases the statistical significance of the parameter estimates was reduced.
} 
becomes larger when interacted with the ratio of foreign-to-total assets. For example, the second specification reports an interaction coefficient of -0.56 , implying that an excess foreign tax credit firm with half its assets abroad invests at an annual rate of $2.8 \%\left[\left(-0.56^{*}(1 / 2)^{2}\right) / 5\right]$ lower than a comparable deficit foreign tax credit firm. When industry dummies and tax loss carryforwards are added to the specification, the coefficient increases in magnitude, reaching -0.69 in the specification reported in column 5. The same regressions, when run using data on PPE accumulation over the 1984-1986 time period, produce estimated interaction coefficients that are positive rather than negative (though not significantly different from zero). Table 5b presents estimated coefficients from these regressions.

There are two possible interpretations of the tendency for firms with excess foreign tax cradits and high ratios of foreign to total assets to accumulate PPE more slowly than do other firms. The first is that the loss of debt tax shields experienced by these firms results in a higher overall cost of capital, and, consequently, a lower level of investment. Of course, to the extent that tirms substitute away from debt finance toward cheaper after-tax financing sources, these substitutions can mitigate the increased cost of capital. The second interpretation is that firms do not face any increase in the cost of employing capital, but that they reduce PPE expenditures by leasing rather than owning capital. Leases allow the leasor to use the debt tax shield from debt financing of PPE, since the capital cost component of lease prices is not allocated between foreign and domestic source. Thus, leases may represent low-cost devices to preserve the tax shield for given amount of PPE. This suggests that excess foreign tax credit firms - particularly those with higher foreign asset ratios -- had incentives to expand more rapidly the use of leases than did deficit foreign tax credit firms.

Table 6 a reports our attempts to test this latter interpretation. We regress a measure of unexpected increases in lease committments over the 1986-91 period on the same explanatory

\footnotetext{
${ }^{32}$ As above, percentage figures are expressed relative to beginning-of-period assets.
} 
variables used in earlier regressions. The dependent variable is unexpected increases in leases because that variable measures the differential effect of the 1986 tax act. It is unlikely that the interest allocation rules enacted at the end of 1986 were understood in detail in prior to that year. In any case, to the extent that such changes were anticiaptaed, the power of our tests is reduced. In order to measure unexpected increases in lease committments, the numerator of the dependent variable equals the difference between actual lease payments in each year from 1986 to 1990 and the tive year lease committments as of December 1985. This difference is scaled by 1986 assets. Table 6a reports the results from regressing this measure on right-hand side variables similar to those in previous tables.

The first specification uses only the foreign tax credit dummy variable, finding there to be a small difference between excess foreign tax credit and deficit foreign tax credit firms. Similarly, both the foreign asset ratio and interaction term are statistically insignificant when added to the regression (as reported in column 2). One possibility is that the colinearity between these two terms, particularly the collinearity introduced by errors in measurement of the ratio of foreign assets to total assets, is responsible for the insignificance of individual coefficients. Column 3 reports estimated coefficients from specifications that omit the foreign-to-total-assets ratio term. Omitting this ratio imposes the restriction that there is no relationship between foreign assets and leases among deticit foreign tax credit firms. This restriction cannot be rejected by the data, since the estimated coefticient on the ratio of foreign assets in the specification reported in column $\mathbf{2}$ is statistically indistinguishable from zero.

The estimates presented in column 3 indicate that the interaction-term coefficient increases in magnitude and becomes statistically significant once the asset ratio restriction is imposed. The interaction coefficient reported in column 3 implies that, among excess foreign tax credit firms, a 50 percent difference in the fraction of total assets that are foreign-held is associated with an average 
difference in unexpected leases over five years of $25 \%\left[1.00(1 / 2)^{2}\right]$ of assets, or about $5 \%$ per year.

The estimated coefficient on the interaction term is also large and marginally

significant when the simple foreign tax credit status dummy variable is added (as in the specification reported in column 4). These results therefore suggest that deficit foreign tax credit furms on average do more leasing than excess foreign tax credit firms (the reverse of what one might expect); however, excess foreign tax credit firms with larger ratios of assets held abroad show a stronger tendency to lease. Overall, Table 6 a provides some evidence that excess foreign tax credit firms with high ratios of assets abroad tend to engage in additional, unexpected leasing subsequent to 1986. Table $6 \mathrm{~b}$ reports estimated coefficients from identical regressions that include industry dummy variables; the results are similar, though of lower statistical significance.

To the extent that firms increase their leasing to avoid higher debt costs for onbalance-sheet assets, they are able to mitigate tax-induced changes in financing costs. The results reported in Table 6a therefore provide some support for alternative hypothesis (I), although they by no means rule out hypothesis (II). Indeed, the evidence presented in Tables $4 \mathrm{a}-6 \mathrm{~b}$ suggests that financing responses did occur, but not that operating responses did not occur. Thus, there appears to be evidence against the null hypothesis, and some evidence in favor of hypothesis (I), but one cannot rule out hypthesis (11).

\section{Changes in Operating Patterns}

One way to obtain additional evidence on hypotheses (I) and (II) is to investigate the level of firms' foreign operations. For example, by examining changes in foreign sales, and foreign costs of production (with and without financing costs), one might gain a better sense for whether excess foreign tax credit firms changed their operations as a result of higher capital costs.

Unfortunately, relatively little data on firms' foreign operations is available. In this section we use 
different measures of operations, although in some cases we are forced to employ data that combine foreign and domestic operating information.

The first variable that measures changes foreign operations is foreign-produced foreign sales. This variable is the difference between sales by foreign affiliates and intrafirm exports from the United States. This variable identifies firms that avoid higher capital costs by substituting away from foreign assets toward domestic assets, as reflected by a proclivity to service foreign markets by exporting rather than using local production.

Tables $7 \mathrm{a}$ and $7 \mathrm{~b}$ report estimated coefficients from regressions that use foreignproduced foreign sales as the dependent variable. In the regressions reported in Table $7 \mathrm{a}$, the independent variables are similar to those presented in Tables $4 a-6 b$, with the difference that debu/assets is used as a regressor in Table 7a place of foreign assets/total assets. The reason for this substitution is that the margin of substitution tested in these regressions is one in which greater indebtedness raises the cost of each dollar of foreign assets, and not one in which the foreign asset ratio is appropriately held constant. If the tax change induces operating effects, the reason must be that firms find it costly to substitute away from debt financing. Thus, excess foreign tax credit firms with high levels of debt in 1986 will not, in these instances, be able inexpensively to reconsitute their capital strucutures, and thus are more likely to reduce their foreign-produced foreign sales.

The first specification reported in Table $7 \mathrm{a}$ indicates that excess foreign tax credit firms on average reduce foreign-produced foreign sales by about 5.7 percent over five years relative to deficit firms; this effect is not, however, statistically different from zero. Column 2 reports estimated coefficients from a more precise specification in which the foreign tax credit dummy variable is interacted with the ratio of debt to total assets. The estimated coefficient on this interaction term is significant, and indicates that firms with excess foreign tax credits and $25 \%$ debtto-asset ratios reduced their foreign sales by $2 \%$ a year (relative to assets) after 1986 . Columns 3-5 
of Table 7 a report the results of alternative specifications in which the estimated interaction effect remains negative while exhibiting reduced statistical significance.

Table $7 \mathrm{~b}$ presents similar regressions that include an addition variable conditioning on the amount of debt in the capital structure as of 1986 . The results are similar to those presented in Table 7a. Together, the results reported in Tables $7 \mathrm{a}$ and $7 \mathrm{~b}$ provide mild support for hypothesis Il above, i.e., that firms responded to the tax change by cutting back on their foreign operations instead of tilly absorbing the increase in capital costs.

One logical implication of the preceding analysis is that the interest allocation rules, by raising the cost of domestic operations and raising the cost of foreign operations, depress the level of tolal business operations by impacted firms. Since the magnitude of total business operations is influenced by many important nontax factors, and, as a practical matter, can be measured in more than one way, this is a challenging hypothesis to test.

Table 8a presents estimated coefficients from regressions in which the dependent variables are changes in costs of goods sold between 1986 and 1991 (scaled by assets in 1986). The cost of gouds sold variable includes foreign and domestic costs. In order to simplify matters, the independent variables are the same as those used in the regressions reported in Table 4a. Table 8a indicates that the tax effects take the expected negative sign - firms affected by the interest allocation rules reduced the scales of their operations - but the estimated coefficients are insignificant in every case. The statistical insiginificance of the coefficients no doubt reflects, at least in part, the impossibility of controlling for many important factors that influence changes in costs of goods sold over this period. The evidence is certainly consistent with a sizable impact of interest allocation rules on scales of operation (the point estimate in the regression reported in column 3 of Table 8 a implies that costs of goods sold were reduced by $2 \% /$ year, relative to assets, for affected firms with $25 \%$ foreign assets), but it is not possible to reject the hypothesis that there was no impact on operations. 
Table $8 \mathrm{~b}$ presents the results of specifications that repeat this estimation, taking as the dependent variable changes in costs of goods sold over 1984-1986. Again, the tax terms are insignificant, though they are of opposite sign to those reported in Table 8a. Taken together, the regressions reported in Tables $8 \mathrm{a}$ and $8 \mathrm{~b}$ provide suggestive but inconclusive (from a statistical standpoint) evidence that interest allocation rules may influence the overall magnitude of firm operations.

\section{Conclusion}

This paper examines the impact of interest allocation rules introduced by the Tax Reform Act of 1986. The incomplete tax deductibility of parent-company interest expenses appears to reduce significantly borrowing and investing by excess foreign tax credit firms. In addition, excess foreign tax credit firms aftected by the interest allocation rules are the most likely to undertake new operating leases, presumably in lieu of acquiring new capital. These results are consistent with the hypothesis that firms substitute away from debt when it becomes more expensive, as well as the hypothesis that loss of interest tax deductibility can increase a firm's cost of capital.

Note, however, that the size and significance of the effects on borrowing, investment spending and leasing do not imply that interest allocation rules necessarily impose large costs on excess foreign tax credit firms. All of the results just mentioned might appear even though non-debt finaneing substitutes are available at essentially the same cost as debt finance. If, for example, leasing can be done at the same after-tax cost as buying, then the tax law change may just encourage low-cost substitution.

Of course, many of the results are also consistent with the proposition that excess foreign tax credit firms face relatively greater costs of capital. Firms may choose to fund property, plant, and equipment off the balance sheet as a way of capturing part of the otherwise-lost tax shields. 
The portion that cannot be captured is a real cost. This may lead excess foreign tax credit firms to underinvest, to grow more slowly, and to restrict the scope of foreign operations; this behavior, in turn, reduces their needs for debt financing. Some of the results reported in the paper suggest that firms affected by the change in interest allocation rules reduced their foreign and total operations in response. The tax law change may also skew investments by affected firms away from businesses in which the tax deductions are crucial to be competitive. In this way, the loss of U.S. multinational tax shields could represent substantial firm-specific costs. 


\section{References}

Altshuler, Rosanne, and Jack Mintz (1994), "U.S. Interest Allocation Rules: Effects and Policy," NBER Working Paper No. 4712, April.

Collins, Julie H., and Douglas A. Shackelford (1992), "Foreign Tax Credit Limitations and Preferred Stock Issuances," Journal of Accounting Research, 30, 103-123.

Edwards, J.S.S. and C.P. Mayer (1991), "Leasing, Taxes, and the Cost of Capital, "Journal of Public Economics, 44, 173-197.

Froot, Kenneth A. and James R. Hines Jr. (1994), "Losing Interest: Interest Allocation Rules and the Cost of Debt Finance," mimeograph, Harvard University.

Gurdon, Roger H. and Burton G. Malkiel (1981), "Corporation Finance," in Henry J. Aaron and Joseph A. Pechman, wls. How Toxes Affect Economic Behavior (Washington, D.C.: Brookings).

Hartman, David G. (1985), "Tax Policy and Foreign Direct Investment," Journal of Public Economics, 26, 107-121.

Hines, James R., Jr. (1991), "The Flight Paths of Migratory Corporations," Journal of Accourting, Auditing, and Finance, 6, 447-479.

Hines, James R., Jr. and R. Glenn Hubbard (1990), "Coming Home to America: Dividend Repatriations by U.S. Multinationals," in Assaf Razin and Joel Slemrod eds. Taxation in the Global Economy (Chicago: University of Chicago Press).

Hines, James R., Jr. and Eric M. Rice (1994), "Fiscal Paradise: Foreign Tax Havens and American Business," Quarterly Journal of Economics, 109, 149-182.

Lyon, Andrew B. and Gerald Silverstein (1993), "The Alternative Minimum Tax and the Behavior of Multinational Corporations," mimeograph, University of Maryland.

Miller, Merton H. (1977), "Debt and Taxes," Journal of Finance, 32, 261-275.

Scholes, Myron S. and Mark A. Wolfson (1992), Taxes and Business Strategy: A Planning Approach (Englewood Cliffs, NJ: Prentice Hall).

Smith, Clifford W., Jr., and L. MacDonald Wakeman (1985), "Determinants of Corporate Leasing Policy", Journal of Finance, 40, 895-908.

Stiglitz, Joseph E., (1973), "Taxation, Corporate Financial Policy, and the Cost of Capital, "Journal of Public Economics, 2, 1-34. 
Figure 1

Debt Accumulation 1986-1991 (as a Fraction of 1986 Assets), by Tax Status

$\Delta$ Debe/1986 Assets

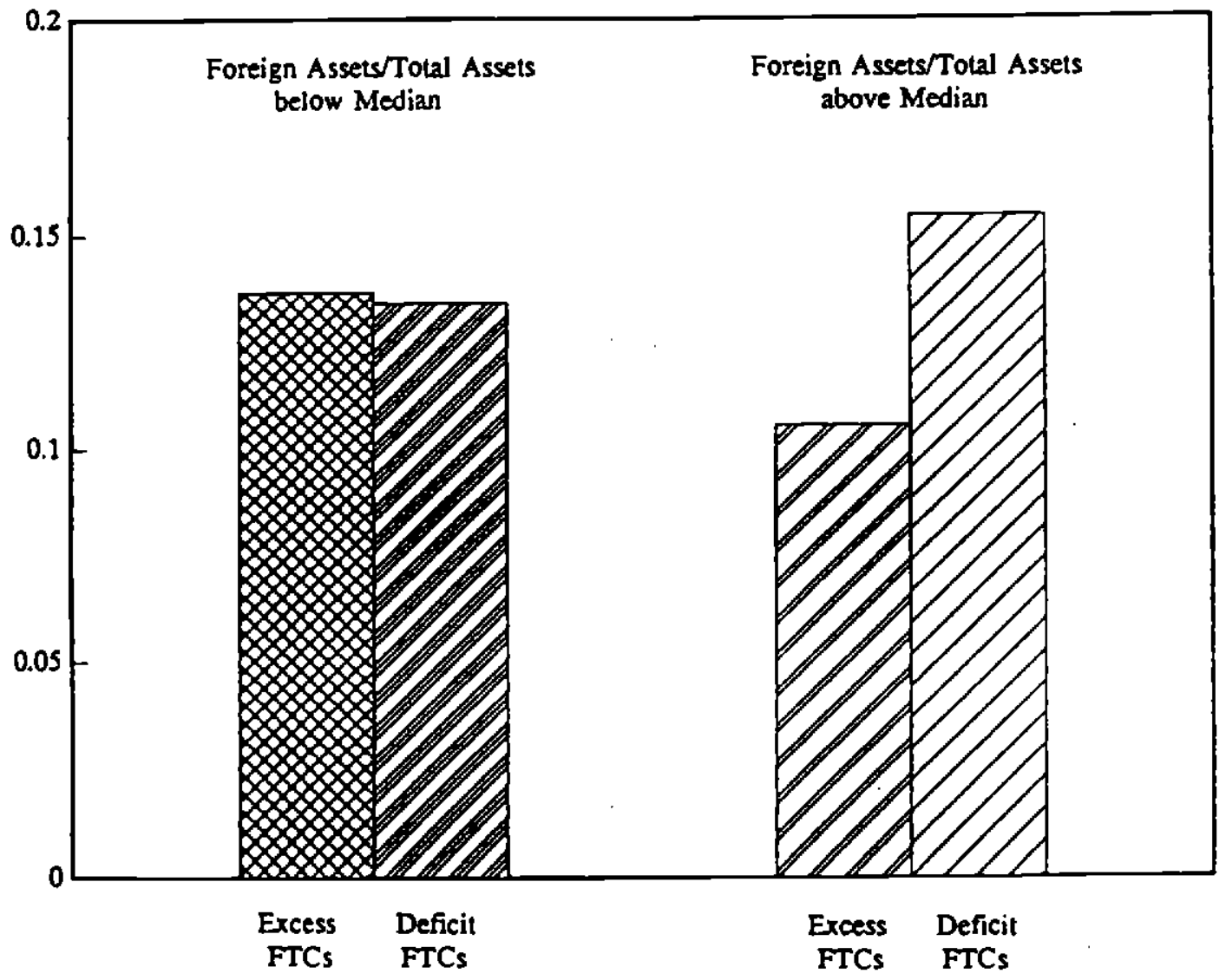

Note: Bars measure the ratios of 5-year changes (1986-1991) in book values of debt w 1986 book assets. Entries depict the mean ratlo for firms in each cell. 193 firms bad below-median ratios of foreign assets to wotal assets in 1986, of which 97 were classified as having excess foreign tax credits and 96 were classified as having deficit foreign tax credits. 193 firms had above-median ratios of foredgn assets to toeal assets, of which 92 were classified as having excess foreign tax credits, and 101 as having deficit foreign tax credits. 
Figure 2

PPE Accumulation 1986-1991 (as a Fraction of 1986 Assets), by Tax Status $\triangle P P E / 1986$ Assets

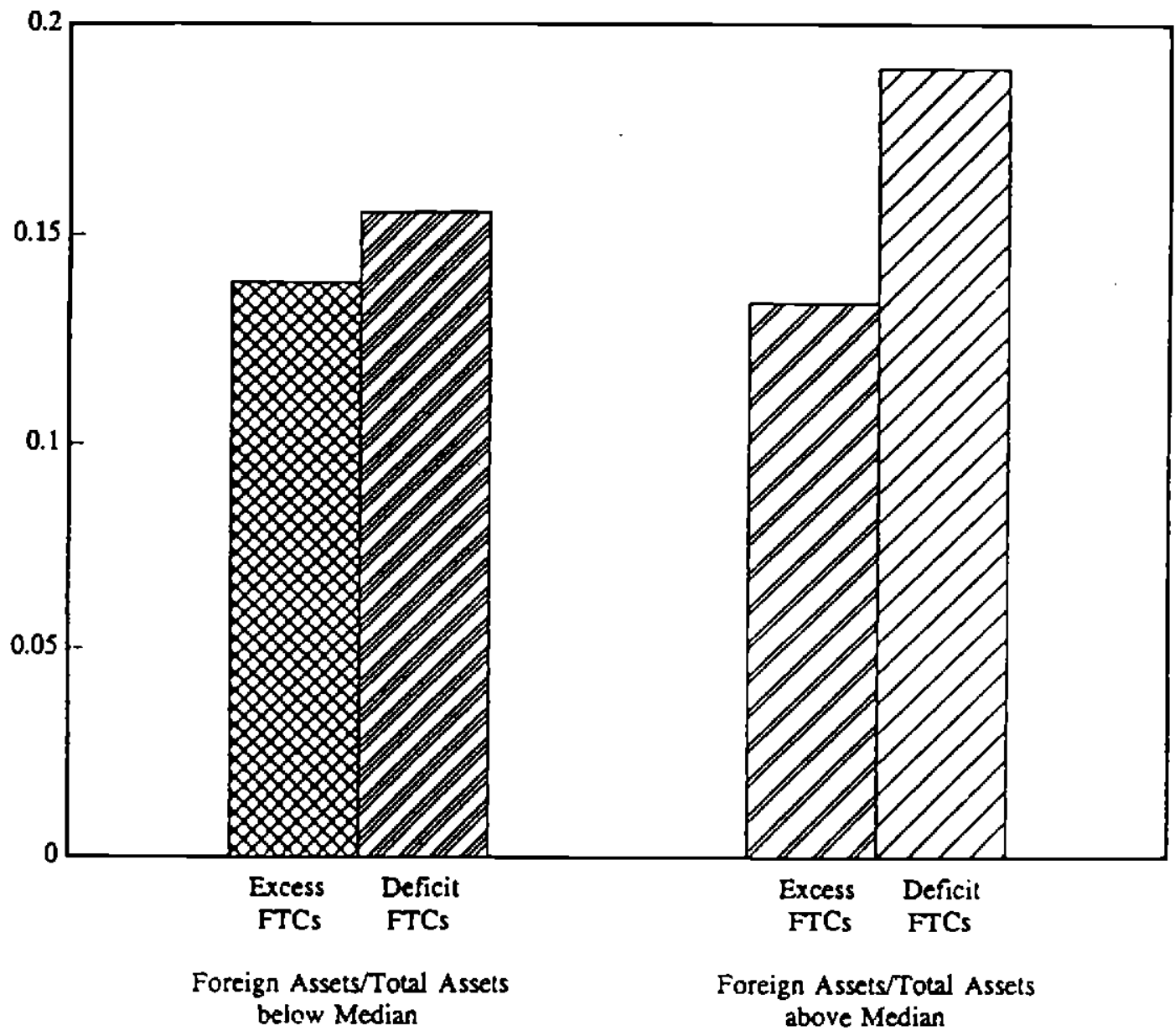

Note: Bars measure the ratios of 5-year changes (1986-1991) in book values of property, plant, and equipment to 1986 book assets. Entries depict the mean ratio for firms in each cell. 193 firms had below-median satios of foreign assets to total assets in 1986, of which 97 were classified as having excess foreign tax credits and 96 were classified as having deficit foreign ux credits. 193 firms had above-median satios of foreign assets to total assets, of which 92 were classified as having excess foreiga tax credits, and 101 as having deficlt foreign tax credits. 
Table 1

Variable Means and Standard Deviations

Variable $\quad$ Mean $\quad$ Standard Deviation $\quad$ No. Obs.

$\Delta$ Debt 1986-1991/Assets 1986

0.2089

0.4566

416

$\triangle$ Debt 1984-1986/Assets 1986

0.1341

0.5254

386

$\triangle$ PPE 1986-1991/Assets 1986

0.2003

0.3903

414

$\triangle$ PPE 1984-1986/Assets 1986

0.0874

0.2024

385

New Leases, 1986-1991/Assets 1986

0.4315

0.8298

286

$\Delta$ Forcign Sales/Assets 1986

0.3114

0.7089

409

$\Delta$ Cost 1986-1991/Assets 1986

0.5051

0.9709

416

$\Delta$ Cost $198+1986 /$ Assets 1986

0.1750

0.8093

385

FTC dummy

0.4808

0.5002

416

$\left[A^{*} /\left(A+A^{*}\right)\right]^{2}$

0.0836

0.1104

416

FTC dummy $\cdot\left[A^{*} /\left(A+A^{*}\right)\right]^{2}$

0.0400

0.0930

416

Tax Loss Carry $/$ Assets

0.0487

0.2432

387

Debt/Assets, 1986

0.2373

0.1887

416

FTC dummy $\cdot[$ Debt/Assets]

0.1132

0.1705

416

Note: Debt represents the book value of total (domestic plus foreign) debt. Assets 1986 represents the book value of total assets at yearend 1986. PPE is the book value of property, plant and equipment. New Leases represents the difference between actual lease expenditures and long-term commitments at the start of the period. $\Delta$ Foreign Sales represents foreign-produced foreign sales over the 1986-1991 period: the difference between total foreign sales and exports from the United States. $\Delta$ Cost is the change in total (domestic plus foreign) cost of goods sold. The FTC dummy variable takes the value one if a firm has excess foreign tax credits, and zero otherwise. The term $\left[A^{*} /\left(A+A^{*}\right)\right]$ is the ratio of a firm's foreign assets to its total assets in 1986 . The variable Tax Loss Carry/Assets is the ratio of tax loss carryforwards to total assets at yearend 1986. Debt/Assets is the ratio of the book value of debt to the book value of total assets at yearend 1986. 
Table 2

Debt and PPE Accumulation, 1986-1991, by Foreign Asset Concentration and FTC Stutus

\begin{tabular}{|c|c|c|c|c|}
\hline & \multicolumn{2}{|c|}{$\begin{array}{l}\text { Foreign Assets/Total Assets } \\
\text { below Median }\end{array}$} & \multicolumn{2}{|c|}{$\begin{array}{c}\text { Foreign Assets/Total Assets } \\
\text { above Median }\end{array}$} \\
\hline & Excess FTC & Deficit FTC & Excess FTC & Deficit FTC \\
\hline \# of firms & 97 & 96 & 92 & 101 \\
\hline \multicolumn{5}{|c|}{ (Change in Debt)/Assets: } \\
\hline $\begin{array}{l}\text { Mean } \\
\text { Median } \\
\text { Std. Dev. }\end{array}$ & $\begin{array}{l}0.13678 \\
0.11705 \\
0.28151\end{array}$ & $\begin{array}{l}0.13426 \\
0.05519 \\
0.22383\end{array}$ & $\begin{array}{l}0.10556 \\
0.06016 \\
0.12348\end{array}$ & $\begin{array}{l}0.15447 \\
0.14446 \\
0.24886\end{array}$ \\
\hline \multicolumn{5}{|c|}{ (Change in PPE)/Assets: } \\
\hline $\begin{array}{l}\text { Mean } \\
\text { Median } \\
\text { Std. Dev. }\end{array}$ & $\begin{array}{l}0.13847 \\
0.11121 \\
0.24350\end{array}$ & $\begin{array}{l}0.15538 \\
0.07145 \\
0.29645\end{array}$ & $\begin{array}{l}0.13395 \\
0.13104 \\
0.22000\end{array}$ & $\begin{array}{l}0.18940 \\
0.14902 \\
0.29366\end{array}$ \\
\hline
\end{tabular}

Note: Firms are classified into cells based on foreign asset/total asset ratios in 1986, and by foreign tax credit (FTC) status as calculated over the 1986-1991 time period. (Change in Debt)/Assets represents the difference between total debt in 1991 and total debt in 1986, divided by total assets in 1986. (Change in PPE)/Assets represents the difference between net property, plant, and equipment in 1991 and net property, plant, and equipment in 1986, divided by total assets in 1986. 
Table 3

Changes in Preferred Stock, 1986-1991, by Foreign Asset Concentration and FTC Status

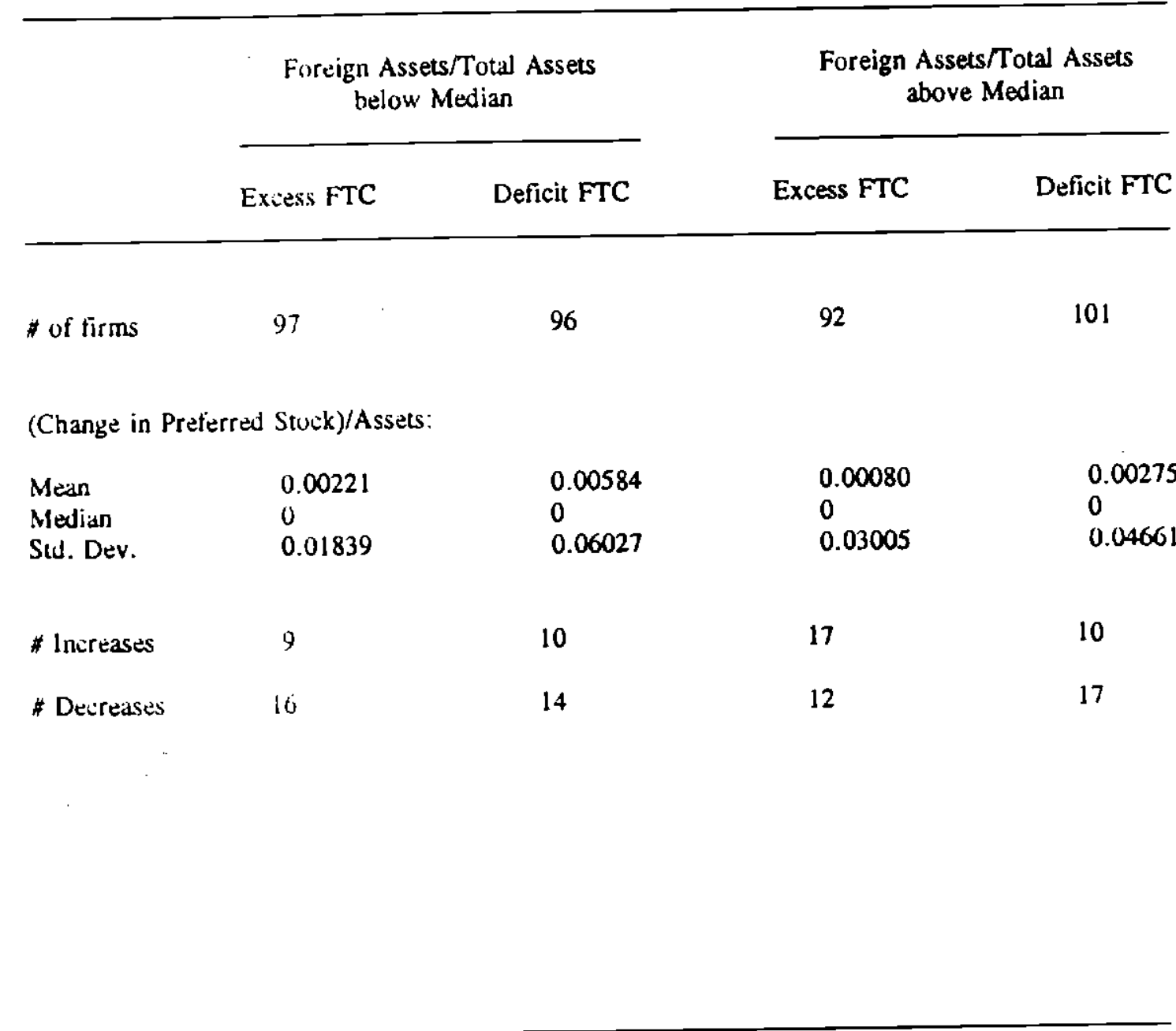

Note: Firms are classitied into cells based on foreign asset/total asset ratios in 1986, and by foreign tax credit (FTC) status as calculated over the 1986-1991 time period. (Change in Preferred Stock)/Assets represents the difference between preferred stock outstanding in 1991 and preferrod stock outstanding in 1986, divided by total assets in 1986. Increases indicates the number of firms in each cell for whom the difference between preferred stock outstanding in 1991 and preferred stock outstanding in 1986 is positive; \# Decreases indicates the number of firms for which the difference is negative. 
Table 4a

Debt Accumulation, 1986-1991

Dependent Variable: Change in Debt, 1986-1991/Assets 1986

$\begin{array}{cccc}\text { Constant } & 0.2256 & 0.1907 & 0.1893 \\ & (0.0311) & (0.0281) & (0.0293)\end{array}$

FTC dummy $\quad-0.0348$

(0.0448)

$\left[\mathbf{A}^{*} /\left(\mathbf{A}+\mathbf{A}^{*}\right)\right]^{2}$

0.5243

0.8858

$(0.2737)$

$(0.3309)$

0.5469

0.9237

$-0.6410$

$-0.9253$

$(0.2765)$

(0.3354)

FTC dummy

$\left[A^{*} /\left(A+A^{*}\right)\right]^{2}$

(0.3247)

$(0.3628)$

$-0.6724$

$-0.9698$

Tax Loss Carryf

$-0.2588$

(0.3288)

$(0.3669)$

Assets

$(0.1005)$

$-0.2791$

(0.1012)

Industry

No

No

No

Yes

Yes

dummies

adj. $R^{2}$

$-0.001$

0.006

0.021

0.010

0.027

No. Obs.

416

416

387

416

376

Note: Standard errors are in parentheses. The columns report coefficients from OLS regressions in which the dependent variable is the ratio of the change in the book value of a firm's debt between 1986-1991 to its total assets in 1986. The FTC dummy takes the value one if a firm's average foreign tax rate exceeds the average US statutory corporate tax rate over the 1987-1991 period; the dummy is zero otherwise. The term $\left[A^{*} /\left(A+A^{*}\right)\right]$ is the ratio of a firm's foreign assets to its total assets in 1986. The term [Tax Loss Carry/Assets] is the ratio of tax loss carryforward at yearend 1986 to firm assets at yearend 1986. 
Table $4 b$

Debt Accumulation, 1984-1986

Dependent Variable: Change in Debt, 1984-1986/Assets 1986

$\begin{array}{cccc}\text { Constant } & 0.1285 & 0.1819 & 0.1900 \\ & (0.0371) & (0.0340) & (0.0362)\end{array}$

FTC dummy $\quad 0.0115$

$(0.0536)$

$\left[A^{*} /\left(A+A^{*}\right)\right]^{2}$

$-0.7118$

$-0.6585$

$-0.7250$

$-0.6844$

$(0.3228)$

(0.4048)

(0.3297)

$(0.4150)$

FTC dummy .

0.2911

0.2636

0.2793

0.2627

$\left[A^{*} /\left(A+A^{*}\right)\right]^{2}$

(0.3997)

$(0.4540)$

(0.4059)

(0.4609)

Tax Loss Carry/

$-0.1215$

$-0.1178$

Assets

(0.1192)

(0.1215)

Industry

No

No

No

Yes

Yes

dummies

adj. $R^{2}$

$-0.002$

0.009

0.008

$-0.004$

$-0.006$

No. Obs.

386

386

362

386

362

Note: Standard errors are in parentheses. The columns report coefficients from OLS regressions in which the dependent variable is the ratio of the change in the book value of a firm's debt between $198+1986$ to its total assets in 1986. The FTC dummy takes the value one if a firm's average foreign tax rate exceeds the average US statutory corporate tax rate over the 1987-1991 period; the dummy is zero otherwise. The term $\left[A^{*} /\left(A+A^{*}\right)\right]$ is the ratio of a firm's foreign assets to its total assets in 1986. The term [Tax Loss Carry/Assets] is the ratio of tax loss carryforward at yearend 1986 to firm assets at yearend 1986. 
Table 5a

PPE Accumulation, 1986-1991

Dependent Variable: Change in Property, Plant, and Equipment, 1986-1991/Assets 1986

$\begin{array}{cccc}\text { Constant } & 0.2358 & 0.1844 & 0.1848 \\ & (0.0266) & (0.0241) & (0.0251)\end{array}$

FTC dummy $\quad-0.0739$

$(0.0383)$

$\left[A^{*} /\left(A+A^{*}\right)\right]^{2}$

$\begin{array}{cccc}0.4592 & 0.6469 & 0.4032 & 0.5888 \\ (0.2344) & (0.2837) & (0.2366) & (0.2869)\end{array}$

FTC dummy •

$\left[A * /\left(A+A^{*}\right)\right]^{2}$

$-0.5613$

$-0.6892$

$-0.5545$

$-0.6855$

(0.2781)

(0.3112)

(0.2814)

(0.3138)

Tax Loss Carry/

$-0.2057$

$-0.2181$

Assets

(0.0861)

(0.0824)

Industry

No

No

No

Yes

Yes

dummies

$\operatorname{adj} \cdot \mathbf{R}^{2}$

0.007

0.007

0.016

0.013

0.027

No. Obs.

414

414

386

414

386

Note: Standard errors are in parentheses. The columns report coefficients from OLS regressions in which the dependent variable is the ratio of the change in the book value of a firm's property, plant, and equipment between 1986-1991 to its total assets in 1986. The FTC dummy takes the value one if a firm's average foreign tax rate exceeds the average US statutory corporate tax rate over the 19871991 period; the dummy is zero otherwise. The term $\left[A^{*} /\left(A+A^{*}\right)\right]$ is the ratio of a firm's foreign assets to its total assets in 1986. The term [Tax Loss Carry/Assets] is the ratio of tax loss carryforward at yearend 1986 to firm assets at yearend 1986. 
Tuble 5b

PPE Accumulation, 1984-1986

Dependent Variable: Change in Property, Plant, and Equipment, 1984-1986/Assets 1986

$\begin{array}{lc}\text { Constant } & 0.0825 \\ & (0.0143) \\ & \\ \text { FTC dummy } & 0.0104 \\ & (0.0207)\end{array}$

\begin{tabular}{|c|c|c|c|c|c|}
\hline$\left|A^{*} /\left(A+A^{*}\right)\right|^{2}$ & & $\begin{array}{l}-0.1512 \\
(0.1250)\end{array}$ & $\begin{array}{l}-0.0765 \\
(0.1536)\end{array}$ & $\begin{array}{l}-0.1418 \\
(0.1236)\end{array}$ & $\begin{array}{l}-0.0765 \\
(0.1524)\end{array}$ \\
\hline $\begin{array}{l}\text { FTC dummy } \\
\left|\mathbf{A}^{*} /\left(\mathbf{A}+\mathbf{A}^{*}\right)\right|^{2}\end{array}$ & & $\begin{array}{c}0.1888 \\
(0.1547)\end{array}$ & $\begin{array}{c}0.1568 \\
(0.1721)\end{array}$ & $\begin{array}{c}0.1183 \\
(0.1520)\end{array}$ & $\begin{array}{c}0.0973 \\
(0.1691)\end{array}$ \\
\hline $\begin{array}{l}\text { Tax Loss Carry/ } \\
\text { Assets }\end{array}$ & & & $\begin{array}{l}-0.1281 \\
(0.0452)\end{array}$ & & $\begin{array}{l}-0.1343 \\
(0.0446)\end{array}$ \\
\hline $\begin{array}{l}\text { Industry } \\
\text { dummies }\end{array}$ & No & No & No & Yes & Yes \\
\hline adj. $R^{2}$ & -0.002 & 0.000 & 0.021 & 0.051 & 0.070 \\
\hline No. Obs. & 385 & 385 & 361 & 385 & 361 \\
\hline
\end{tabular}

Note: Standard errors are in parentheses. The columns report coefficients from OLS regressions in which the dependent variable is the ratio of the change in the book value of a firm's property, plant and equipment between 1984-1986 to its total assets in 1986. The FTC dummy takes the value one if a firm's average foreign tax rate exceeds the average US statutory corporate tax rate over the 19871991 period; the dummy is zero otherwise. The term $\left[A^{*} /\left(A+A^{*}\right)\right]$ is the ratio of a firm's foreign assets to its total assets in 1986. The term [Tax Loss Carry/Assets] is the ratio of tax loss carryforward at yearend 1986 to firm assets at yearend 1986. 
Tuble 6a

New Leases, 1986-1991

Dependent Variable: New Leases, 1986-1991/Assets 1986

\begin{tabular}{|c|c|c|c|c|c|}
\hline Constant & $\begin{array}{c}0.4694 \\
(0.0690)\end{array}$ & $\begin{array}{c}0.3871 \\
(0.0530)\end{array}$ & $\begin{array}{c}0.3608 \\
(0.0611)\end{array}$ & $\begin{array}{c}0.4710 \\
(0.0891)\end{array}$ & $\begin{array}{c}0.3842 \\
(0.0561)\end{array}$ \\
\hline FTC dummy & $\begin{array}{l}-0.0768 \\
(0.0982)\end{array}$ & & & $\begin{array}{l}-0.2071 \\
(0.1221)\end{array}$ & \\
\hline$\left[A^{*} /\left(A+A^{*}\right)\right]^{2}$ & & & $\begin{array}{c}0.5597 \\
(0.6473)\end{array}$ & $\begin{array}{l}-0.0205 \\
(0.7303)\end{array}$ & \\
\hline $\begin{array}{l}\text { FTC dummy } \\
{\left[A^{*} /\left(A+A^{*}\right)\right]^{2}}\end{array}$ & & $\begin{array}{c}0.9994 \\
(0.4681)\end{array}$ & $\begin{array}{c}0.5309 \\
(0.7162)\end{array}$ & $\begin{array}{c}1.4469 \\
(0.8952)\end{array}$ & $\begin{array}{c}1.0152 \\
(0.4793)\end{array}$ \\
\hline $\begin{array}{l}\text { Tax Loss Carry/ } \\
\text { Assets }\end{array}$ & & & & & $\begin{array}{c}0.1789 \\
(0.1946)\end{array}$ \\
\hline $\begin{array}{l}\text { Industry } \\
\text { dummies }\end{array}$ & No & No & No & No & No \\
\hline adj. $R^{2}$ & -0.001 & 0.012 & 0.011 & 0.018 & 0.013 \\
\hline No. Obs. & 286 & 286 & 286 & 286 & 268 \\
\hline
\end{tabular}

Note: Standard errurs are in parentheses. The columns report coefficients from OLS regressions in which the dependent variable is a ratio. The numerator of the ratio is the difference between a firm's leases of property, plant and equipment over 1986-1991 and its preexisting lease committments at yearend 1986. The denominator of the ratio is the firm's total assets at yearend 1986. The FTC dummy takes the value one if a firm's average foreign tax rate exceeds the average US statutory corporate tax rate over the 1987-1991 period; the dummy is zero otherwise. The term [A*/(A+A*)] is the ratio of a firm's foreign assets to its total assets in 1986. The term [Tax Loss Carry/Assets] is the ratio of tax loss carryforward at yearend 1986 to firm assets at yearend 1986. 
Table 6b

New Leases, 1986-1991

Dependent Variable: New Leases, 1986-1991/Assets 1986

Cunstant

$\begin{array}{ll}\text { FrC dummy } & -0.0910 \\ & (0.0845)\end{array}$

$-0.2048$

(0.1049)

$\left[A^{*} /\left(A+A^{*}\right)\right]^{2}$

0.0972

$-0.4883$

(0.5589)

(0.6318)

FrC dummy *

$\left[A^{*} /\left(A+A^{*}\right)\right]^{2}$

\begin{abstract}
0.5654
\end{abstract}
0.4845

(0.4157)

(0.6247)

1.3867

(0.7744)

0.6105

Tax Luss Carry

Assets

0.1114

$(0.1683)$

Industry

Yes

Yes

Yes

Yes

Yes

dummies

adj. $R^{2}$

0.281

0.283

0.281

0.288

0.268

No. Obs.

286

286

286

286

268

Note: Standard errors are in parentheses. The columns report coefficients from OLS regressions in which the dependent variable is a ratio. The numerator of the ratio is the difference between a firm's leases of property, plant and equipment over 1986-1991 and its preexisting lease committments at yearend 1986. The denominator of the ratio is the firm's total assets at yearend 1986. The FTC dummy takes the value une if a firm's average foreign tax rate exceeds the average US statutory corporate tax rate uver the 1987-1991 period; the dummy is zero otherwise. The term [A*/(A+A*)] is the ratio of a firm's foreign assets to its total assets in 1986. The term [Tax Loss Carry/Assets] is the ratio of tax loss carryforward at yearend 1986 to firm assets at yearend 1986. 
Tuble 7a

Foreign-Produced Foreign Sales, 1986-1991

Dependent Variable: Foreign-Produced Foreign Sales, 1986-1991/Assets 1986

\begin{tabular}{|c|c|c|c|c|c|}
\hline Constant & $\begin{array}{c}0.3389 \\
(0.0486)\end{array}$ & $\begin{array}{c}0.3579 \\
(0.0419)\end{array}$ & $\begin{array}{c}0.4169 \\
(0.0562)\end{array}$ & & \\
\hline FTC dummy & $\begin{array}{l}-0.0572 \\
(0.0702)\end{array}$ & & & & \\
\hline Debt/Assets & & & $\begin{array}{l}-0.3319 \\
(0.2110)\end{array}$ & & $\begin{array}{l}-0.2864 \\
(0.2095)\end{array}$ \\
\hline $\begin{array}{l}\text { FTC dummy } \\
\text { [Debu/Assets] }\end{array}$ & & $\begin{array}{l}-0.4151 \\
(0.2069)\end{array}$ & $\begin{array}{l}-0.2442 \\
(0.2334)\end{array}$ & $\begin{array}{l}-0.3043 \\
(0.1927)\end{array}$ & $\begin{array}{l}-0.1583 \\
(0.2201)\end{array}$ \\
\hline $\begin{array}{l}\text { Tax Loss Carry/ } \\
\text { Assets }\end{array}$ & & & & $\begin{array}{l}-0.0979 \\
(0.1340)\end{array}$ & $\begin{array}{l}-0.0766 \\
(0.1347)\end{array}$ \\
\hline $\begin{array}{l}\text { Industry } \\
\text { dummies }\end{array}$ & No & No & No & Yes & Yes \\
\hline adj. $R^{2}$ & -0.001 & 0.007 & 0.011 & 0.003 & 0.013 \\
\hline No. Obs. & 409 & 409 & 409 & 381 & 381 \\
\hline
\end{tabular}

Note: Standard errors are in parentheses. The columns report coefficients from OLS regressions in which the dependent variable is the ratio of the change, from 1986-1991, in a firm's foreign-produced foreign sales [the difference between total foreign sales and exports from the United States] to total assets at yearend 1986. The FTC dummy takes the value one if a firm's average foreign tax rate exceeds the average US statutory corporate tax rate over the 1987-1991 period; the dummy is zero otherwise. Debt/Assets is the ratio of the book value of debt to the book value of total assets at yeurend 1986. The term [Tax Loss Carry/Assets] is the ratio of tax loss carryforward at yearend 1986 to firm assets at yearend 1986. 
Table $7 \mathbf{b}$

Foreign-Produced Foreign Sales, 1986-1991

Dependent Variable: Foreign-Produced Foreign Sales, 1986-1991/Assets 1986

\begin{tabular}{|c|c|c|c|c|c|}
\hline Constant & $\begin{array}{c}0.2033 \\
(0.0697)\end{array}$ & $\begin{array}{c}0.2623 \\
(0.0789)\end{array}$ & & & \\
\hline Debt/Assets & & $\begin{array}{l}-0.3302 \\
(0.2093)\end{array}$ & & & $\begin{array}{l}-0.2321 \\
(0.2085)\end{array}$ \\
\hline $\begin{array}{l}\text { FTC dummy } \\
\text { [Debu/Assets] }\end{array}$ & $\begin{array}{l}-0.4045 \\
(0.2053)\end{array}$ & $\begin{array}{l}-0.2344 \\
(0.2315)\end{array}$ & $\begin{array}{l}-0.3747 \\
(0.2076)\end{array}$ & $\begin{array}{l}-0.2936 \\
(0.1908)\end{array}$ & $\begin{array}{l}-0.1760 \\
(0.2182)\end{array}$ \\
\hline $\begin{array}{l}\text { Tax Loss Carry/ } \\
\text { Assets }\end{array}$ & & & & $\begin{array}{c}-0.1890 \\
(0.1362)\end{array}$ & $\begin{array}{l}-0.1685 \\
(0.1374)\end{array}$ \\
\hline $\begin{array}{l}\text { Foreign Assets/ } \\
\text { Total Assets }\end{array}$ & $\begin{array}{c}0.6231 \\
(0.2254)\end{array}$ & $\begin{array}{c}0.6220 \\
(0.2249)\end{array}$ & $\begin{array}{c}0.5911 \\
(0.2272)\end{array}$ & $\begin{array}{c}0.6502 \\
(0.2215)\end{array}$ & $\begin{array}{c}0.6273 \\
(0.2224)\end{array}$ \\
\hline $\begin{array}{l}\text { Industry } \\
\text { dummies }\end{array}$ & No & No & Yes & Yes & Yes \\
\hline $\operatorname{adj} . R^{2}$ & 0.023 & 0.027 & 0.033 & 0.023 & 0.013 \\
\hline No, Obs, & 409 & 409 & 409 & 381 & 381 \\
\hline
\end{tabular}

Note: Standard errors are in parentheses. The columns report coefficients from OLS regressions in which the dependent variable is the ratio of the change, from 1986-1991, in a firm's foreign-produced foreign sales [the difference between total foreign sales and exports from the United States] to total assets at yearend 1986. The FTC dummy takes the value one if a firm's average foreign tax rate exceeds the average US statutory corporate tax rate over the 1987-1991 period; the dummy is zero otherwise. Debu/Assets is the ratio of the book value of debt to the book value of total assets at yearend 1986. The term [Tax Loss Carry/Assets] is the ratio of tax loss carryforward at yearend 1986 to firm assets at yearend 1986. Foreign Assets/Total Assets is the ratio of book values of foreign assets and total assets in 1986. 
Table 8a

Change in Scale of Operations, 1986-1991

Dependent Variable: Change in Cost of Goods Sold, 1986-1991/Assets 1986

$\begin{array}{cccc}\text { Constant } & 0.5660 & 0.4561 & 0.4485 \\ & (0.0660) & (0.0599) & (0.0632)\end{array}$

FTC dummy $\quad-0.1267$

$(0.0952)$

$\left[A * /\left(A+A^{*}\right)\right]^{2}$

FTC dummy *

$\left[A^{*} /\left(A+A^{*}\right)\right]^{2}$

Tax Loss Carry/

Assets

Industry

dummies

adj. $R^{2}$

No. Obs.

$$
\begin{array}{r}
1.0492 \\
(0.5829)
\end{array}
$$

\subsection{4}

(0.7145)

0.9010

(0.5840)

1.5615

$-0.9659$

(0.6914)

$-1.4156$

(0.7835)

$-0.9265$

(0.6945)

$-1.3650$

(0.7861)

$-0.4890$

$(0.2170)$

$-0.4981$

$(0.2167)$

No

No

No

Yes

Yes

0.002

0.003

0.014

0.024

0.035

416

416

387

416

387

Note: Standard errors are in parentheses. The columns report coefficients from OLS regressions in which the dependent variable is the ratio of the change in a firm's total (domestic plus foreign) cost of goods sold between 1986-1991 to its total assets in 1986. The FTC dummy takes the value one if a firm's average foreign tax rate exceeds the average US statutory corporate tax rate over the 19871991 period; the dummy is zero otherwise. The term [ $\left.A^{*} /\left(A+A^{*}\right)\right]$ is the ratio of a firm's foreign assets to its total assets in 1986. The term [Tax Loss Carry/Assets] is the ratio of tax loss carryforward at yearend 1986 to firm assets at yearend 1986. 
Table 8b

Change in Scale of Operations, 1984-1986

Dependent Variable: Change in Cost of Goods Sold, 1984-1986/Assets 1986

\begin{tabular}{|c|c|c|c|c|c|}
\hline Constant & $\begin{array}{c}0.2058 \\
(0.0571)\end{array}$ & $\begin{array}{c}0.4561 \\
(0.0599)\end{array}$ & $\begin{array}{c}0.4485 \\
(0.0632)\end{array}$ & & \\
\hline FTC dummy & $\begin{array}{l}-0.0645 \\
(0.0826)\end{array}$ & & & & \\
\hline$\left[A^{*} /\left(A+A^{*}\right)\right]^{2}$ & & $\begin{array}{l}-0.5799 \\
(0.5001)\end{array}$ & $\begin{array}{l}-0.3883 \\
(0.6263)\end{array}$ & $\begin{array}{l}-0.6469 \\
(0.5059)\end{array}$ & $\begin{array}{l}-0.4708 \\
(0.6348)\end{array}$ \\
\hline $\begin{array}{l}\text { FTC dummy } \\
{\left[A^{*} /\left(A+A^{*}\right)\right]^{2}}\end{array}$ & & $\begin{array}{c}0.2256 \\
(0.6189)\end{array}$ & $\begin{array}{c}0.1216 \\
(0.7020)\end{array}$ & $\begin{array}{c}0.2388 \\
(0.6224)\end{array}$ & $\begin{array}{c}0.1419 \\
(0.7044)\end{array}$ \\
\hline $\begin{array}{l}\text { Tax Loss Carry/ } \\
\text { Assets }\end{array}$ & & & $\begin{array}{l}-0.3072 \\
(0.1844)\end{array}$ & & $\begin{array}{l}-0.3199 \\
(0.1856)\end{array}$ \\
\hline $\begin{array}{l}\text { Industry } \\
\text { dummies }\end{array}$ & No & No & No & Yes & Yes \\
\hline adj. $R^{2}$ & 0.002 & -0.001 & 0.004 & 0.005 & 0.013 \\
\hline No. Obs. & 385 & 385 & 361 & 385 & 361 \\
\hline
\end{tabular}

Note: Standard errors are in parentheses. The columns report coefficients from OLS regressions in which the dependent variable is the ratio of the change in a firm's total (domestic plus foreign) cost of goods sold between 1984-1986 to its total assets in 1986. The FTC dummy takes the value one if a firm's average foreign tax rate exceeds the average US statutory corporate tax rate over the 19871991 period; the dummy is zero otherwise. The term $[A * /(A+A *)]$ is the ratio of a firm's foreign assets to its total assets in 1986. The term [Tax Loss Carry/Assets] is the ratio of tax loss carryforward at yearend 1986 to firm assets at yearend 1986. 